\title{
Fetal procedures during COVID-19 pandemic: Challenges in a newly developing centre
}

\author{
Manu Goyal ${ }^{1 *}$, Pratibha Singh $^{2}$ and Aparajita ${ }^{3}$ \\ ${ }^{1}$ Associate Professor, Department of Obstetrics \& Gynecology, All India Institute of Medical Sciences, Jodhpur, India. \\ ${ }^{2}$ Professor \& Head, Department of Obstetrics \& Gynecology, All India Institute of Medical Sciences, Jodhpur, India. \\ ${ }^{3}$ Post Graduate student, Department of Obstetrics \& Gynecology, All India Institute of Medical Sciences, Jodhpur, India.
}

Corresponding Author: Manu Goyal, Associate Professor, Department of Obstetrics \& Gynecology, All India Institute of Medical Sciences, Jodhpur, India.

Received date: February 15, 2021; Accepted date: February 18, 2021; Published date: March 02,2021

Citation: Goyal M., Singh P. and Aparajita (2021) Fetal procedures during COVID-19 pandemic: Challenges in a newly developing centre. J. of Obstetrics Gynecology and Reproductive Sciences. 5(2): DOI: 10.31579/2578-8965/064

Copyright: (C) 2021, Manu Goyal, This is an open access article distributed under the Creative Commons Attribution License, which permits unrestricted use, distribution, and reproduction in any medium, provided the original work is properly cited.

Abstract
Prenatal invasive diagnostic and therapeutic procedures have drastically reduced during COVID-19 pandemic.
Unlike routine prenatal care, these are time bound and highly skilled procedures available at specialized
centres. This adds to the limited accessibility for at-risk women. Major concerns including procedure related
risk, exposure of health care personnel and vertical transmission of COVID-19. At newly developing tertiary
centre, we had done 36 fetal procedures during pandemic including 25 amniocentesis, three chorion villus
sampling and eight intrauterine transfusions. It is advisable to perform life-saving fetal interventions
irrespective of COVID-19 status taking full precautions and proper counselling of women.
Keywords: Prenatal; invasive; COVID-19; challenges
Running Title: Challenges in fetal procedures during COVID-19 era

\section{Introduction}

COVID-19 pandemic has affected the health care globally and this is the reason for stress to both the patient and health workers. It has posed a major challenge in the practice of prenatal care. This is more so for prenatal invasive procedures for fetal diagnostic and therapeutic purpose [1]. The prenatal invasive procedures are done in high risk pregnancies where biochemical screen is positive for aneuploidies, fetal anomaly on ultrasound or previous history of anomalous baby is there. These procedures include chorion villus sampling (CVS), amniocentesis, cordocentesis and intrauterine transfusion for fetal anaemia, laser therapy for twin-twin transfusion syndrome and fetal shunt surgeries. Unlike routine prenatal care, these are time bound interventions sensitive to particular gestational age so these cannot be delayed or postponed. Moreover, these highly skilled procedures are available at specialized centres only. This adds to the limited accessibility of health-care by atrisk women during the pandemic where there are curfew restrictions, modified policies for hospital admissions and disruptions in routine antenatal programs. There are many concerns in performing fetal interventions. These include procedure related risk to fetus and mother, exposure of health care personnel and vertical transmission to the fetus if women tests positive for covid-19. These risks have to be weighed against the benefit of mother and fetus [2].

There have been advisory for fetal interventions from the North American Fetal Therapy Network in August 2020 which states that most of these are non-elective so they should be considered even during pandemic [3].
Our experience: At newly developing tertiary care centre in western India, we had done 36 fetal procedures during the lockdown period from April, 2020 till October, 2020. Out of this, 25 were amniocentesis and three CVS (indication being biochemical screen positive for trisomies, abnormal anomaly scan or previous affected child with congenital adrenal hyperplasia). There were eight intrauterine transfusions performed for Rh-isoimmunisation with severe fetal anaemia. All women were tested for COVID-19 and they were reported negative. This was to ensure the safety of all patients, healthcare workers and also to counsel women regarding risk of vertical transmission in case she is positive for COVID19. The procedures were done taking informed consent, proper precautions by staff and doctors (personal protective equipment-PPE). There were no complications in any of the procedures.

It is recommended to test all women for COVID-19 infection prior to the procedure. If women is tested positive, then the procedure should be ideally postponed till the clearance of infection. Non-invasive prenatal screening can be offered in these women due to high sensitivity of about 99\% and it may be more useful in COVID-19 times as it provides wide window for testing. Certain procedures are dependent on period of gestation like intra-uterine transfusions for fetal anemia and laser therapy for twin-twin transfusion syndrome. Hence, it is advisable to perform lifesaving fetal interventions irrespective of COVID-19 status while taking full precautions so as to minimise the risk of viral transmission to health workers. The procedure in a COVID-19 positive patient should be 
performed with minimal staff in the operation theatre and after wearing PPE. There is risk of vertical transmission of virus to fetus which should be explained to women and family, although it has not been proved in recent studies [4]. This risk can be further minimised by avoiding transplacental passage of the needle as far as possible and amniocentesis may be preferred to chorion villus sampling [5]. Thus, there is a major concern in performing fetal procedures during the pandemic, which should be done after proper counselling of the couple taking into account their background risks and feasibility at the facility.

\section{Conflict of interest:}

None declared.

\section{References:}

1. Ozalp M, Demir O, Akbas H, Kaya E, Celik C, Osmanagaoglu MA (2020): Effect of COVID-19 pandemic process on prenatal diagnostic procedures. J Matern-Fetal Neonatal Med.
2. Deprest J, Choolani M, Chervenak F, (2020) et al. Fetal diagnosis and therapy during the COVID-19 Pandemic: Guidance on behalf of the International Fetal Medicine and Surgery Society. Fetal Diagn Ther.: 47:689-698.

3. Bahtiyar MO, Baschat A, Deprest J, (2019) et al. Fetal interventions in the setting of the coronavirus disease pandemic: Statement from the North American Fetal Therapy Network. Am J Obstet Gynecol. 223:281-284.

4. Chen H, Guo J, Wang C, Luo F, Yu X, Zhang W, (2020) et al. Clinical characteristics and intrauterine vertical transmission potential of CO- VID-19 infection in nine pregnant women: a retrospective review of medical records. Lancet. 395(10226):80915 .

5. Rasmussen SA, Smulian JC, Lednicky JA, Wen TS, Jamieson DJ. (2020) Coronavirus Disease 2019 (COVID-19) and pregnancy: what obstetricians need to know. Am J Obstet Gynecol; 222(5):S0002-9378(20)30197-6.
This work is licensed under Creative Commons Attribution 4.0 License

To Submit Your Article Click Here: Submit Manuscript

DOI: $10.31579 / 2578-8965 / 064$
Ready to submit your research? Choose Auctores and benefit from:

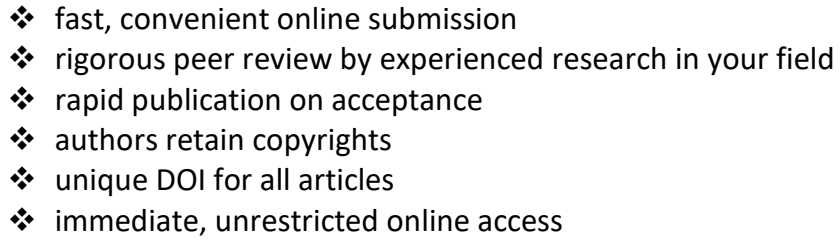

At Auctores, research is always in progress.

Learn more www.auctoresonline.org/journals/ Obstetrics Gynecology and Reproductive Sciences 